\title{
Możliwości wykorzystania bezzałogowej fotogrametrii lotniczej do identyfikacji przekształceń antropogenicznych w korytach rzecznych
}

\author{
Possibilities of using unmanned air photogrammetry to identify anthropogenic \\ transformations in river channel
}

\author{
Matylda Witek, Justyna Jeziorska, Tomasz Niedzielski \\ Instytut Geografii i Rozwoju Regionalnego, Uniwersytet Wrocławski,Wrocław,matylda.witek@uni.wroc.pl
}

Zarys treści: Przestrzenny charakter antropogenicznych zmian w obrębie koryt rzecznych wymaga zastosowania metod i narzędzi umożliwiających nie tylko jakościową, ale i ilościową ich analizę. Pomiary geodezyjne są bardzo dokładne, lecz kosztowne i czasochłonne, co sprawia, że regularne ich wykonywanie, potrzebne do określenia dynamiki form fluwialnych, jest trudne do zrealizowania. Tradycyjna fotogrametria lotnicza to wartościowe źródło informacji jedynie w przypadku analizy większych form korytowych. Skala, w jakiej najcześciej wykonywane są zdjęcia lotnicze, nie zapewnia wystarczającej szczegółowości do analizy niewielkich form rzeźby. W niniejszej publikacji zaprezentowane zostanie użycie bezzałogowego statku powietrznego (ang. UAV, Unmanned Aerial Vehicle), który wypełnia lukę między pomiarami naziemnymi a tradycyjną fotogrametrią czy analizą obrazów satelitarnych. Ultralekki bezzałogowy statek powietrzny swinglet CAM wyposażony jest w kompaktowy aparat fotograficzny wykonujący sekwencje zdjęć, które po przetworzeniu mogą służyć jako źródło kartometrycznych danych przestrzennych. Zniekształcenia geometryczne zdjęć oraz zniekształcenia spowodowane pochyleniem aparatu i rzeźbą terenu są usuwane w procesie wieloetapowego przetwarzania. Dzięki wysokiej rozdzielczości materiałów obserwacyjnych (do $3 \mathrm{~cm} \mathrm{px}^{-1}$ ), wygenerowane ortofotomapy umożliwiają analizę nawet niewielkich form korytowych. Teren badań - Kotlina Kłodzka - jest doskonałym przykładem występowania zmian fluwialnych o podłożu antropogenicznym i - z uwagi na ten fakt - został wybrany jako obszar testowy do prezentacji możliwości bezzałogowego statku powietrznego w zakresie zdalnego wykrywania omawianych form. Wyniki potwierdzają dużą szczegółowość pozyskanych materiałów, co - w połączeniu z niskimi kosztami misji lotniczych oraz łatwością dostosowania parametrów i czasu realizacji lotów - jednoznacznie pokazuje, że zastosowana technologia jest odpowiednim narzędziem do obserwacji antropogenicznych form fluwialnych i może przyczynić się do rozwiązywania wielu problemów badawczych dotyczących ich roli w kształtowaniu procesów hydrologicznych.

Słowa kluczowe: bezzałogowy statek powietrzny, wysokorozdzielcze ortofotomapy, koryta uregulowane, zabudowa hydrotechniczna, ziemia kłodzka

\begin{abstract}
Spatial character of anthropogenic fluvial changes requires the use of methods and tools eligible for not only qualitative, but also quantitative analysis. Geodetic surveys are very accurate, but time and cost consuming, what makes repetitive measurements needed for determining the dynamics of fluvial landforms hard to perform. Traditional aerial photogrammetry is a valuable source only for examining features visible in a small cartographic scale. Hence, small fluvial forms cannot be observed using traditional aerial photogrammetry due to its limitations in resolution. Unmanned Aerial Vehicles (UAVs), presented extensively in this paper, serve as the additional source of high-resolution spatial information and thus fill the gap between terrestrial measurements and traditional aerial photogrammetry as well as satellite data. Ultra-light unmanned aircraft swinglet CAM, with consumer-grade camera onboard, provides sequences of pictures, which after geoprocessing can serve as source of spatial data eligible for quantitative measurements. Geometric incorrectness of the acquired pictures and distortions caused by tilt and relief are removed in the process of multistep processing. Due to high resolution of the observational material (up to $3 \mathrm{~cm} \mathrm{px}^{-1}$ ) the generated orthophotomaps are appropriate for the analysis of small fluvial features. The study area namely Kłodzko County - serves as a great example of assemblages of anthropogenic fluvial changes and - due to this fact - has been chosen as a test area to present potentials of UAV in observing the aforementioned landforms. The results confirm a great accuracy of the collected materials, which - in combination with low cost surveys, ease of parameter adjustment and flight schedule - unequivocally shows that the applied technology is an appropriate tool for observing anthropogenic fluvial forms, and thus may contribute to solutions of numerous research problems related to hydrological processes impacted by human interventions.
\end{abstract}

Key words: UAV (Unmanned Aerial Vehicles), high-resolution orthophotomap, regulated channels, hydraulic engineering structure, Kłodzko County 


\section{Wstęp}

Formy korytowe - niezależnie od tego, czy powstały na skutek naturalnych procesów fluwialnych, czy też działalności człowieka - mają różny zasięg i charakterystyki przestrzenne, które zmieniają się w czasie. Obserwacja tych form jest konieczna $\mathrm{z}$ uwagi na fakt, że ich obecność i dynamika w systemie fluwialnym wpływają na procesy hydrologiczne w zlewni, w szczególności na formowanie się przepływu (np. Verbanck 2008). Ma to implikacje dla szeroko pojętych studiów na temat powodzi, gdyż zmienna w czasie i przestrzeni forma korytowa modyfikuje nie tylko przepływ na określonych zamknięciach zlewni, ale też decyduje o przestrzennym zasięgu obszarów podtapianych (np. Knight, Brown 2001). Zachodzi również odwrotna zależność: formy korytowe podlegają modyfikacji przez zachodzące $\mathrm{z}$ różną intensywnością procesy hydrologiczne (np. Loveless i in. 2000, Warmink i in. 2012). Mimo że uwzględnienie dynamiki omawianych form w modelach hydrologicznych jest trudne, ich identyfikacja i dokładne określenie charakterystyk pozwalają na prognozowanie potencjalnych scenariuszy wezbrań i powodzi.

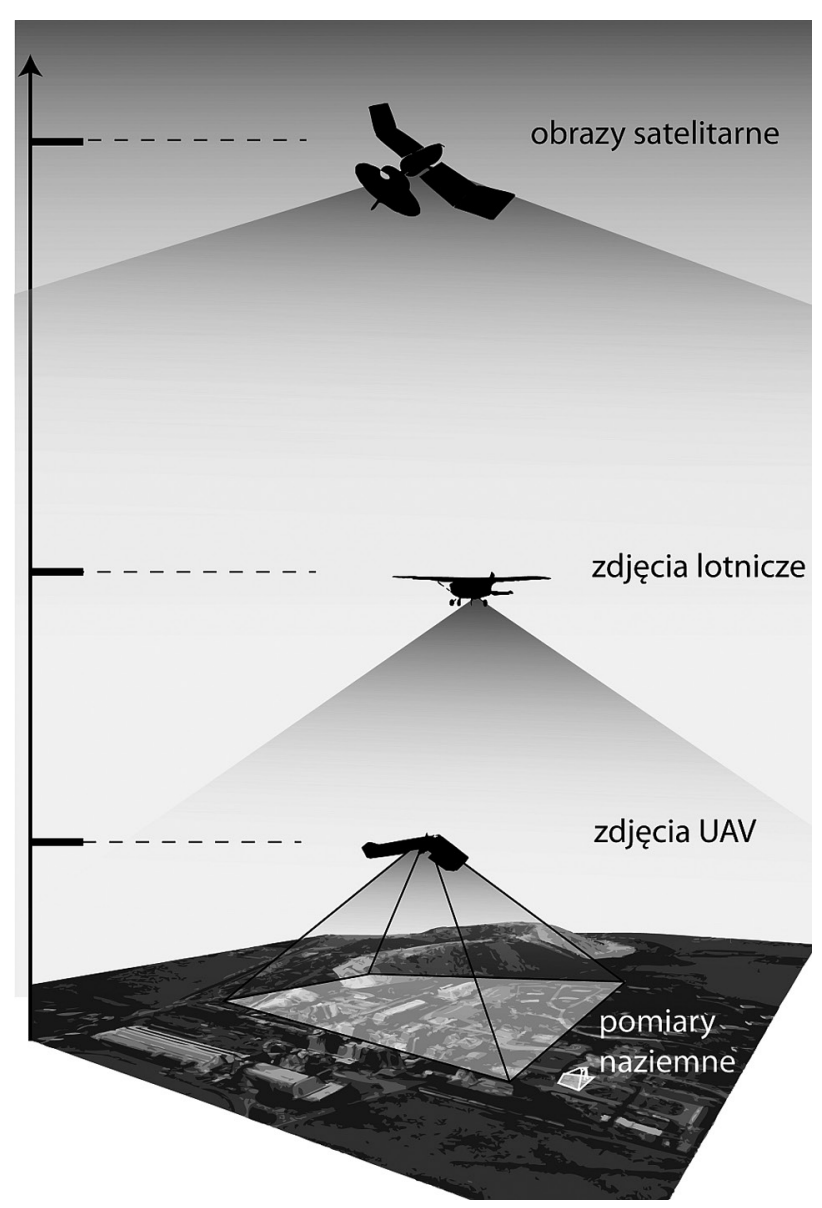

Ryc. 1. Obserwacje satelitarne i lotnicze - różne poziomy wysokości pozyskiwania danych przestrzennych

Fig. 1. Satellite and aerial observations - different ranges of spatial data acquisition
Największą trudnością w wykrywaniu i identyfikacji form fluwialnych jest konieczność wykonania kartowania w terenie zwykle na długich odcinkach wzdłuż rzeki. Formy te powinny być dokładnie i ilościowo charakteryzowane, co wymaga drogich pomiarów geodezyjnych stosowanych do określenia ich morfologii (Brasington $i$ in. 2000, Radecki-Pawlik i in. 2005) oraz zaawansowanych technik geofizycznych umożliwiających rozpoznanie wewnętrznej budowy form (Vandenberghe, van Overmeeren 1999, Słowik 2011). Pomiary te są jednak trudne do przeprowadzenia na długich odcinkach rzek. Alternatywą dla geodezyjnych pomiarów naziemnych i często obarczonego dużym stopniem subiektywizmu kartowania geomorfologicznego są metody teledetekcyjne (ryc. 1) z użyciem materiałów fotogrametrycznych (Lane 2000) czy satelitarnych (Singh i in. 2007) oraz innych obserwacji, np. z wykorzystaniem coraz bardziej powszechnego skaningu laserowego (np. Wieczorek i in. 2012). Zdalne pomiary form korytowych mogą być prowadzone - w zależności od szczegółowości analizy i wielkości obszaru badań - z ziemi lub z powietrza. Jedną z pierwszych prób zastosowania fotointerpretacji do określania zmian morfologii koryt rzecznych w Polsce jest studium Dobrowolskiego i in. (2004), którzy użyli metody wideo-komputerowej w ramach nalotów nad korytem Wisły powyżej Warszawy.

Rozdzielczość i związana z nią szczegółowość dostępnych obecnie satelitarnych danych o terenie czy materiałów dostarczanych przez tradycyjną fotogrametrię lotniczą są zwykle niewystarczające, by wykryć i oszacować morfometryczne charakterystyki małych form fluwialnych. Przykładem są ortofotomapy państwowego zasobu geodezyjnego i kartograficznego, udostępniane przez Centralny Ośrodek Dokumentacji Geodezyjnej i Kartograficznej (CODGiK) i tylko dla małych obszarów wykonywane przy terenowej wielkości piksela $10 \mathrm{~cm}$. Alternatywą jest fotogrametria niskiego pułapu realizowana przez bezzałogowe statki powietrzne, poruszające się na wysokościach przelotowych od stu do kilkuset metrów. Dane przestrzenne pozyskiwane przez te urządzenia mają kilkucentymetrową rozdzielczość, a niski koszt misji pozwala na powtarzanie obserwacji, co umożliwia określenie dynamiki form fluwialnych.

Szczególnie ważnym zagadnieniem w kontekście analizy morfologii koryt rzecznych jest obecnie szeroko dyskutowany w Polsce (Kościelniak 2005, Korpak 2007a, b, Witek 2007, 2010a, b, 2012, Korpak i in. 2009a, b, Latocha 2009) i na świecie (Kondolf 1997, Surian 1999, Herget 2000) temat antropogenicznych przekształceń w obrębie koryt oraz wpływ obiektów regulacyjnych na funkcjonowanie całych systemów korytowych. Obecność w korytach rzecznych zabudowy hydrotechnicznej oraz różnorodnych systemów regulacji w większości przypadków zasadniczo zmienia naturalny układ koryta oraz wpływa na rozmieszczenie stref erozji i akumulacji. Najbardziej efektywne zmiany morfologiczne zachodzą w bezpośrednim sąsiedztwie sztucznych obiektów w korycie, a ich zasięg ma zazwyczaj charakter lokalny. Jed- 
nak występują także sytuacje, gdy pojedyncza ingerencja w korycie powoduje zmiany obserwowane na całej długości cieku. Dzieje się tak dlatego, że system rzeczny jest złożonym systemem wzajemnie zależnych, współoddziałujących elementów, tworzących układ odcinków powiązanych przepływem energii i materii.

Głównym celem niniejszej pracy jest ukazanie możliwości bezzałogowego statku powietrznego swinglet $C A M$ do pozyskiwania wysokorozdzielczego materiału fotogrametrycznego, umożliwiającego identyfikację przekształceń antropogenicznych w korytach rzecznych oraz przeprowadzenie pomiarów morfometrycznych form korytowych powstałych na skutek działalności człowieka. W artykule prezentowane jest narzędzie badawcze, proces przygotowania i realizacji lotu, sposób przetwarzania pozyskanych zdjęć lotniczych oraz etapy tworzenia wysokorozdzielczej ortofotomapy. Przedstawiony jest wstępny materiał obserwacyjny pozyskany podczas lotów bezzałogowego statku powietrznego nad kilkoma obszarami Kotliny Kłodzkiej w okresie od listopada 2012 do maja 2013 r., a szczególną uwagę poświęcono wskazaniu korytowych form antropogenicznych na nowych wysokorozdzielczych ortofotomapach.

\section{Metody badań}

\section{Bezzałogowy statek powietrzny swinglet $C A M$}

Prezentowane w artykule materiały pozyskano dzięki zastosowaniu bezzałogowego statku powietrznego (ang. UAV - Unmanned Aerial Vehicle) typu swinglet CAM (ryc. 2), wyprodukowanego przez szwajcarską firmę senseFly. Niewielka rozpiętość skrzydeł $(80 \mathrm{~cm})$ oraz waga zaledwie $0,5 \mathrm{~kg}$ sytuuje go w kategorii ultralekkich bezzałogowych statków powietrznych (Küng i in. 2011). Zasilanie baterią litowo-polimerową LiPoly $1350 \mathrm{mAh}$ pozwala

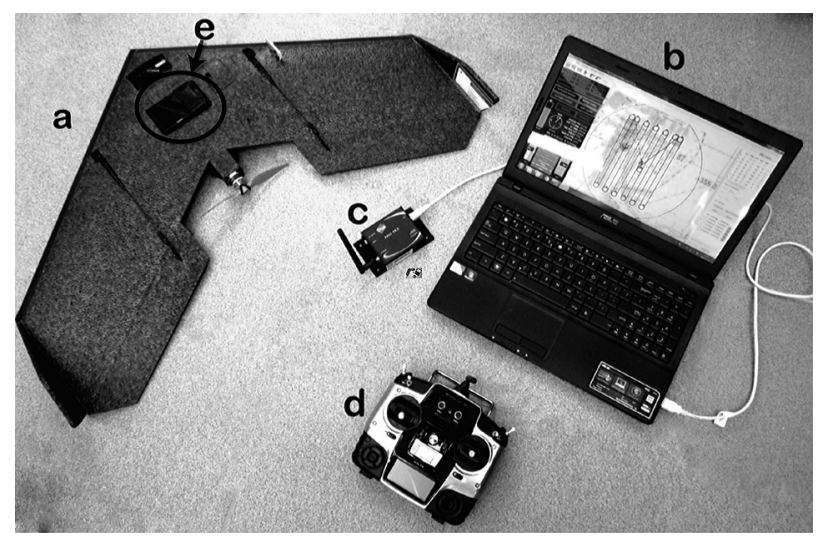

Ryc. 2. System swinglet CAM

a - ultralekki bezzałogowy statek powietrzny (UAV), b - naziemna stacja kontrolna, $\mathrm{c}$ - radiomodem, $\mathrm{d}$ - pilot radiowy, e - aparat fotograficzny $12 \mathrm{MP}$

Fig. 2. Swinglet CAM system comprising

$\mathrm{a}$ - unmanned aerial vehicle (UAV), $\mathrm{b}$ - ground control station, $\mathrm{c}$ - radiomodem, $\mathrm{d}$ - remote control, e - camera 12MP na lot o długości około $30 \mathrm{~min}$. Wbudowany aparat kompaktowy o rozdzielczości 12 MP (specyfikacje w tab. 1) jest zintegrowany $z$ wewnętrznym autopilotem i pozwala na pozyskanie wysokorozdzielczych zdjęć z uprzednio ustalonym pokryciem poprzecznym i podłużnym (nakładanie na siebie sąsiednich zdjęć). Powierzchnia, która może zostać skartowana za pomocą pojedynczego lotu, może osiągnąc nawet $10-15 \mathrm{~km}^{2}$, co jest wykonalne przy założeniu mniejszej rozdzielczości przestrzennej materiałów obserwacyjnych.

System swinglet CAM składa się nie tylko ze statku powietrznego. Samolot stanowi jeden z elementów platformy przedstawionej na rycinie 2. Stosowany anglojęzyczny termin UAS (Unmanned Aerial Systems), tłumaczony zazwyczaj jako bezzałogowe systemy powietrzne, lepiej oddaje wzajemną integrację wszystkich komponentów. Rdzeń systemu stanowi oprogramowanie zainstalowane na komputerze przenośnym służącym jako bazowa stacja kontrolna. Pozwala ono zaplanować i przeprowadzić misję lotniczą i gwarantuje pełną kontrolę lotu dzięki połączeniu statku powietrznego i stacji kontrolnej za pomocą radiomodemu (ryc. 2c). Moduł oparty na sztucznej inteligencji nieprzerwanie analizuje dane dostarczane przez system inercyjny i odbiornik GPS (Global Positioning System). Statek powietrzny cechuje się pełną automatyką od startu, realizowanego przez wypuszczenie statku w powietrze bez konieczności stosowania wyrzutni, do lądowania w promieniu $20 \mathrm{~m}$ od zadanej uprzednio lokalizacji. W przypadku sytuacji krytycznej, gdyby system automatycznego pilotażu zawiódł, istnieje możliwość przejęcia kontroli nad urządzeniem poprzez pilota radiowego (ryc. 2d) obsługiwanego przez doświadczonego operatora. Typowa prędkość lotu statku oscyluje wokół $10 \mathrm{~m} \mathrm{~s}^{-1}$ i zależy przede wszystkim od prędkości wiatru. Pionowe tempo wznoszenia przy starcie wynosi około $3 \mathrm{~m} \mathrm{~s}^{-1}$. Przeprowadzanie misji lotniczych musi odbywać się w odpowiednich warunkach meteorologicznych. Nie można wykonywać lotów w czasie opadów atmosferycznych, możliwe są natomiast loty przy niskim pułapie chmur czy zamgleniu oraz w warunkach wietrznych, o ile prędkość wiatru nie przekracza $7 \mathrm{~m} \mathrm{~s}^{-1}$. Jakość uzyskanych zdjęć jest jednak najlepsza w słoneczne, bezwietrzne dni, przy odpowiednio niskim pułapie lotu. Zdjęcia są gotowe do dalszego przetwarzania po wylądowaniu statku powietrznego i wyjęciu karty pamięci z aparatu fotograficznego.

Tabela 1. Parametry aparatu w bezzałogowym statku powietrznym swinglet CAM

Table 1. Onboard camera parameters used in swinglet CAM Unmanned Aerial Vehicle

\begin{tabular}{ll}
\hline Model aparatu & Canon IXUS-120IS \\
Maksymalna rozdzielczość zdjęcia & $3000 \times 4000 \mathrm{px}$ \\
Efektywne piksele & $12,1 \mathrm{mln}$ \\
Ogniskowa & $5,0-20,0 \mathrm{~mm}$ \\
Format zdjęć & JPG zgodny z EXIF 2.2 \\
\hline
\end{tabular}




\section{Fotogrametria ze zdjęć lotniczych niskiego pulapu}

Wszystkie aparaty fotograficzne pozyskują obrazy bez fizycznego kontaktu z ich źródłem, co, zgodnie z definicją (Paine, Kiser 2003), czyni je narzędziami do teledetekcji. W fotogrametrii lotniczej używa się zdjęć lotniczych w celu wykonania obserwacji terenu i pozyskiwania danych przestrzennych (Slama 1980). Tradycyjna aerofotogrametria wykorzystująca tzw. „prawie pionowe” zdjęcia (oś kamery nachylona nie więcej niż $3^{\circ}$ od płaszczyzny odniesienia) stanowi doskonałe źródło informacji przestrzennych, ale jest opłacalna tylko dla zobrazowań wielkoobszarowych. Ciągle rosnąca potrzeba pozyskiwania informacji przestrzennych oraz łatwy dostęp do wysokorozdzielczych aparatów cyfrowych spowodowały rozwój nowej metody pozyskiwania zdjęć wykorzystywanych do celów fotogrametrycznych: fotografii niskiego pułapu.

Aby procedury używane $\mathrm{w}$ tradycyjnej fotogrametrii lotniczej znalazły zastosowanie przy zdjęciach niskiego pułapu, wykonywanych niemetrycznymi aparatami cyfrowymi, nierzadko odchylonymi w momencie wykonywania zdjęcia znacznie więcej niż $3^{\circ}$ od płaszczyzny odniesienia, należy wziąć pod uwagę wiele dodatkowych czynników (Grenzdörffer 2007):

- zmieniające się powiększenie na skutek aktywnej opcji powiększania,

- obiektyw zmiennoogniskowy,

- minimalny czas ekspozycji potrzebny do zrobienia zdjęcia,

- pojemność dysku zapisującego zdjęcia,

- stabilność elementów orientacji wewnętrznej.

Tradycyjne aparaty fotogrametryczne są skalibrowane, a ich parametry dostępne $\mathrm{w}$ raporcie kalibracji. W przypadku kompaktowego aparatu w bezzałogowym statku powietrznym informacje te muszą być wydobyte z każdego pojedynczego zdjęcia. Fotografia cyfrowa używa podobnych algorytmów do stosowanych w klasycznej fotografii analogowej. Aby dopasować proces ortorektyfikacji do potrzeb fotografii cyfrowej, blokuje się opcję powiększania (tzw. zoom optyczny) oraz modyfikuje procedurę kalibracji (geometrycznej i radiometrycznej).

\section{Ortofotomapy jako materiał badawczy}

Mimo że zdjęcia lotnicze są doskonałym źródłem danych przestrzennych, ich geometria nie nadaje się do zastosowań pomiarowych przez błędy i zniekształcenia topograficzne oraz nachylenie i dystorsję obiektywu. Proces ich dostosowywania polega na zmianie rzutu środkowego, w którym wykonana jest fotografia, na rzut ortogonalny. Proces ten nosi nazwę ortorektyfikacji. Finalny produkt tej procedury zapewnia kartometryczność i poprawność geometryczną materiału. Wysokorozdzielcze ortofotomapy są używane do pozyskiwania informacji o topografii terenu, nawigacji oraz wizualizacji i mogą służyć nie tylko jako podkład w procesie redakcyjnym map, ale znajdują zasto- sowanie $\mathrm{w}$ badaniach różnorodnych zjawisk w naukach przyrodniczych oraz innych dziedzinach. Mikuni (1996) zaryzykował stwierdzenie, że cyfrowe ortofotomapy staną się w kartografii i teledetekcji jednymi z najbardziej uniwersalnych narzędzi XXI w. Prawie dwadzieścia lat później nie ma już wątpliwości, że jego przewidywania się sprawdziły, a potwierdzają to liczne publikacje. Na przykład Vassilopoulou i in. (2002) używali ortofotomap do monitorowania zagrożeń wulkanicznych, a Somodi i in. (2012) korzystali z nich, rozpoznając gatunki inwazyjne. Podejście inżynierskie reprezentują Larsson i Nilsson (2005), którzy wyznaczali koszty dostosowywania opuszczonego gospodarstwa rolnego pod uprawę roślin energetycznych. Niethammer i in. (2012), badając osuwiska, pokazali wykorzystanie ortorektyfikowanych zdjęć w badaniach geologicznych. Zainteresowanie ortofotomapami nie ogranicza się do nauk przyrodniczych i technicznych. Szerokie zastosowanie znajdują one w różnych innych dziedzinach, w tym np. w archeologii (np. Chiabrando i in. 2011, Verhoeven i in. 2012).

\section{Ortofotomapy w hydrologii i geomorfologii fluwialnej}

Zobrazowania lotnicze są powszechnie wykorzystywane w hydrologii i geomorfologii. W przypadku niektórych zjawisk jedynie zdjęcia lotnicze pozwalają na rozpoznanie i badanie danego procesu. Analiza zjawisk o charakterze wielkoobszarowym czy liniowym wymaga specjalnego podejścia. Klasyczne prace terenowe w takich przypadkach są niezwykle czasochłonne, a niekiedy niemożliwe do wykonania ze względu na ograniczenia terenowe (obszary zabagnione, duże, głębokie rzeki, strome, niedostępne ściany skalne) czy własnościowe (brak możliwości dotarcia do koryta rzeki z uwagi na konieczność przejścia przez obszary będące własnością prywatną).

Jednym z działów geomorfologii, w którym zobrazowania lotnicze znajdują szerokie zastosowania, jest geomorfologia fluwialna. Fotogrametria lotnicza i interpretacja obrazu są powszechnie wykorzystywane np. w analizie przestrzennych skutków powodzi. Zdjęcia wykonane z powietrza są źródłem rzetelnej informacji o topografii terenu, obszarze zalania, propagacji fali powodziowej, a także skutkach wezbrania (Bates, De Roo 2000, Kasprzak, Migoń 2010). Szczególnie ważna - nie tylko z naukowego, ale też aplikacyjnego i utylitarnego punktu widzenia - jest możliwość obserwacji zmian morfologii niektórych form korytowych oraz rzeźby obszaru zalewowego, dzięki możliwym do uzyskania seriom zobrazowań $\mathrm{w}$ określonych odstępach czasu. Takie szeregi czasowe map pozwalają na określenie tempa przeobrażania niektórych form oraz kompleksową charakterystykę zachodzących zmian. Dzięki zastosowaniu wysokorozdzielczych zobrazowań lotniczych możliwe jest zatem ustalenie wpływu poszczególnych zjawisk na formy morfologiczne na danym obszarze oraz oszacowanie tempa tych zmian. Zdjęcia lotnicze wykorzystywane były także do analizy zmienności planarnego przebiegu 
koryt oraz monitorowania dynamiki erozyjnych i akumulacyjnych form korytowych (Marcus, Fonstad 2008). Użycie zobrazowań lotniczych pozwala także na identyfikację form rzeźby niewidocznych lub trudnych do rozpoznania bezpośrednio z powierzchni ziemi, np. paleokoryt. Dużym utrudnieniem w wykorzystaniu zdjęć lotniczych w kontekście analiz form rzeźby jest ich niewystarczająca szczegółowość i rozdzielczość. Zobrazowania wykonywane $z$ zastosowaniem tradycyjnej fotogrametrii lotniczej nie pozwalają na szczegółową, dokładną analizę niewielkich form morfologicznych. Obecnie materiały pozyskane przy użyciu tradycyjnej fotogrametrii lotniczej są często zastępowane analizami gotowych cyfrowych modeli terenu o dużej rozdzielczości (Tarboton i in. 2006, Kasprzak, Migoń 2010). Ortofotomapy otrzymane ze zobrazowań satelitarnych wykonanych przez NASA (National Aeronautics and Space Administration) oraz USGS (United States Geological Survey) pozwalają na analizę form fluwialnych w małej skali. Maksymalna rozdzielczość zdjęć uzyskiwana przez satelity najnowszej generacji dochodzi do $41 \mathrm{~cm}$ (GeoEye), jednak nawet ta wysoka rozdzielczość nie wystarcza do analizy poszczególnych form fluwialnych w małej skali. Wysokorozdzielcze zdjęcia lotnicze wykonywano za pomocą m.in. kamer podwieszonych do bezzałogowych balonów oraz helikopterów. Shaw i in. (2011) podkreślają rolę wysokorozdzielczych zobrazowań lotniczych w zrozumieniu mechanizmu zjawisk hydrologicznych, zwłaszcza w sytuacjach, gdy tradycyjne pozyskiwanie danych o terenie jest niemożliwe lub w wysokim stopniu utrudnione.

\section{Generowanie ortofotomapy - etapy geoprzetwarzania}

Aparat fotograficzny umieszczony w bezzałogowym statku powietrznym pozyskuje obraz na zasadzie podobnej do ludzkiego oka. Matematycznym opisem tego ujęcia jest rzut środkowy. Usunięcie perspektywy i geometrycznych zniekształceń jest realizowane w procesie ortorektyfikacji. W przypadku fotografii lotniczej rzut ten wywołuje wrażenie, że obiekty wyższe (położone bliżej aparatu) są większe niż obiekty znajdujące się dalej. Finalny produkt - ortofotografia - jest zobrazowaniem w rzucie ortogonalnym, tj. promienie rzutu są prostopadłe do płaszczyzny rzutowania (w odróżnieniu od rzutu środkowego, gdzie przechodzą one przez wspólny środek rzutu). Dzięki temu ortofotomapa może być używana jako materiał kartograficzny. Przetwarzanie zdjęć analogowych i cyfrowych podlega tym samym regułom geometrycznym, ale sam proces generowania ortofotomapy różni się zastosowaniem odmiennych narzędzi i technik. W przypadku zdjęć cyfrowych elementarnym fragmentem obrazu jest piksel, który podlega przetwarzaniu różniczniczkowemu. Dodatkowe modyfikacje tego procesu należy wprowadzić, gdy materiał źródłowy stanowią zdjęcia pozyskane za pomocą kamery niemetrycznej (jaką jest np. kompaktowy aparat cyfrowy w bezzałogowym statku powietrznym). Czynniki te zostały wyszczególnione wcześniej.
Przebieg procesu ortorektyfikacji zdjęć lotniczych wykonanych aparatami kompaktowymi jest zależny od oprogramowania, w którym jest przeprowadzany, jednak Vallet i in. (2011) wyróżnili wspólne elementy, które pozwalają wyznaczyć następujące kroki czy produkty pośrednie generowania ortofotomapy ze zdjęć lotniczych niskiego pułapu:

1. kalibracja aparatu,

2. orientacja wielozdjęciowa: generowanie chmury punktów na podstawie sekwencji zdjęć,

3. numeryczny model terenu,

4. ortomozaika (ortofotomapa).

W kompaktowym aparacie cyfrowym elementy orientacji wewnętrznej nie są ani znane, ani nawet stałe w czasie (Turner i in. 2012). Problem zdefiniowania orientacji wewnętrznej aparatu (1), jak również orientacji zewnętrznej każdego ze zdjęć, jest rozwiązywany przez przeprowadzenie procedury zwanej Bundle Block Adjustment (Wolf, Dewitt 2000), która w tłumaczeniu na język polski może być określana mianem orientacji wielozdjęciowej (2). W procesie tym pierwotne położenie sensora jest wyznaczane $\mathrm{z}$ odbiornika GPS oraz modułu inercyjnego, a następnie obrazy są łączone ze sobą zgodnie z algorytmem SfM (Structure from Motion), który podobnie jak w przypadku stereowizji bazuje na punktach wspólnych pomiędzy dwoma następującymi po sobie zobrazowaniami (ang. tie points). Finalnym produktem tej procedury jest chmura punktów (ang. point cloud), która pozwala wygenerować numeryczny model terenu (3) i ortofotomapę (4). Tworzenie nowej geometrii dla modelu trójwymiarowego jest procesem czasochłonnym, który może być znacznie przyspieszony, gdy przeprowadza się go na jednostkach o większej mocy obliczeniowej. Rektyfikacja finalnej ortofotomapy wyznacza położenie środka wynikowego piksela na podstawie lokalizacji pozyskanej przez wzajemne orientowanie wielu zdjęć, a mozaikowanie pozwala wygenerować jeden plik zawierający zobrazowanie całego kartowanego obszaru.

\section{Obszar badań}

Prace nad wykorzystaniem bezzałogowej fotogrametrii lotniczej do analizy zjawisk wezbraniowych (głównie stanowiących wsparcie dla systemu HydroProg do prognozowania hydrologicznego), a także do identyfikacji przekształceń antropogenicznych w dolinach rzecznych prowadzone są od listopada 2012 r. na ziemi kłodzkiej, na obszarach testowych w dolinach czterech rzek: Nysy Kłodzkiej, Białej Lądeckiej, Bystrzycy Dusznickiej i Ścinawki (ryc. 3).

Szczególne warunki topograficzne terenu badań - jedno z największych w Sudetach śródgórskich obniżeń (Kotlina Kłodzka) otoczone pasmami górskimi oraz gęsta sieć rzeczna - powodują, że region ten jest bardzo narażony na występowanie katastrofalnych i gwałtownych wezbrań. Dodatkowo ziemia kłodzka charakteryzuje się zwartą siecią osadniczą w większości przypadków ściśle nawią- 


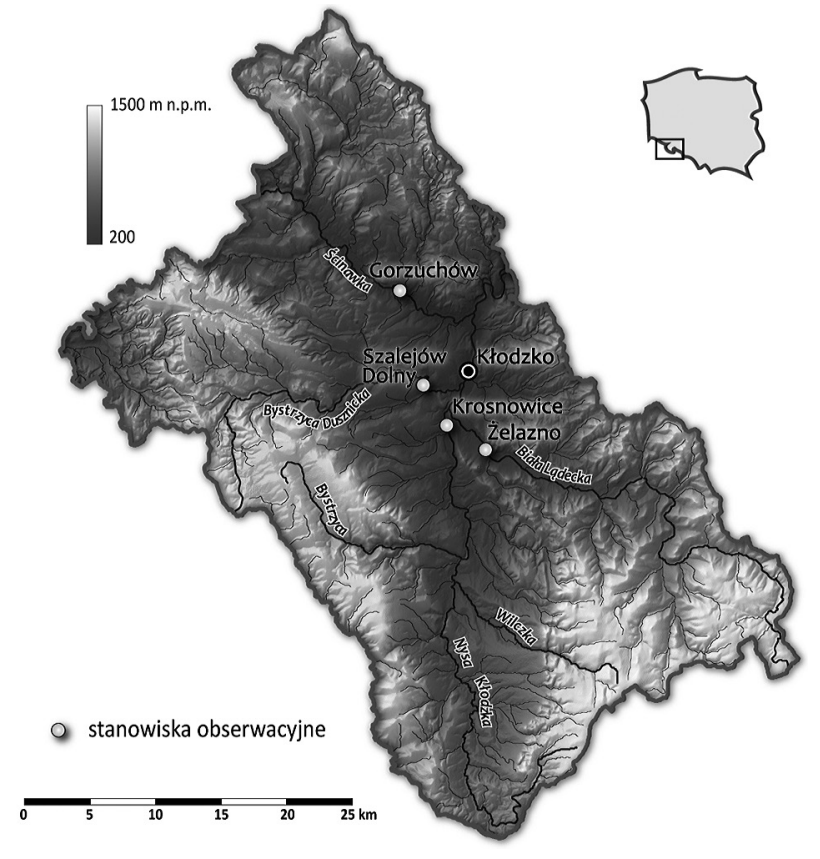

Ryc. 3. Obszar badań

Fig. 3. Research area

zującą do przebiegu dolin głównych rzek obszaru. Cieki, na których prowadzono badania, cechują się znaczącym stopniem przekształcenia koryta. Intensywne wykorzystanie antropogeniczne koryta i doliny cieku przejawia się w obecności różnych form zabudowy hydrotechnicznej, zwłaszcza konstrukcji przeciwpowodziowych i przeciwerozyjnych.

\section{Wyniki}

Loty badawcze bezzałogowym statkiem powietrznym swinglet CAM wykonywane były regularnie od listopada 2012 do maja 2013 r. Pierwsze misje miały charakter testowy. Podczas ich realizacji sprawdzano możliwości techniczne sprzętu, lądowiska oraz parametry wykonywanych zdjęć w zależności od wysokości lotu, procentu nakładania się zdjęć, warunków meteorologicznych. Rozpoznanie tych elementów jest kluczowe dla systemu prognozowania hydrologicznego HydroProg, gdyż bezzałogowy statek powietrzny będzie w nim służył do weryfikacji przestrzennych prognoz zasięgu zalania. Naloty przeprowadzono $\mathrm{w}$ różnych porach roku oraz podczas zróżnicowanych stanów wody w rzekach, co jest wyraźnie widoczne na wykonanych zdjęciach lotniczych.

Uzyskany materiał zdjęciowy oraz przygotowane na jego podstawie ortofotomapy pozwalają na:

- wyróżnienie fragmentów koryta przekształconych antropogenicznie,

- identyfikację form zabudowy hydrotechnicznej oraz form regulacji koryta,

- wykonanie analiz morfometrycznych form korytowych oraz porównanie form w różnych okresach roku,

- analizę sytuacji wezbraniowej w korycie i dolinie rzecznej.

\section{Formy regulacji koryta na zdjęciach niskiego pulapu}

Koryta rzek, nad którymi prowadzono loty, charakteryzują się stosunkowo dużą liczbą fragmentów uregulowanych. Wyniki wcześniejszych prac w korytach rzek ziemi kłodzkiej (Witek 2007, 2012, Latocha 2009, Witek, Latocha 2009), podczas których metodami tradycyjnymi skartowano około $300 \mathrm{~km}$ koryt, pokazują, że około 50\% ich długości poddane zostało różnego typu pracom regulacyjnym (konstrukcje ubezpieczeń brzegowych, profilowanie, prostowanie koryta).

Wysoka rozdzielczość (nawet do $3 \mathrm{~cm} \mathrm{px}^{-1}$ ) materiału fotograficznego pozwala na określenie dokładnej lokalizacji peryferyjnych odcinków ubezpieczeń brzegowych wyróżnienie granicy między odcinkiem przekształconym a naturalnym, w konsekwencji zaś fragmentów brzegu poddany regulacjom (ryc. 4). Ortofotomapa zbudowana na podstawie zdjęć wykonanych nad korytem Bystrzycy Dusznickiej w Szalejowie Dolnym umożliwia wskazanie odcinków uregulowanych i naturalnych. Na rycinie 4 wyraźnie widoczne są różne formy regulacji koryta. Regularny układ lewego brzegu rzeki świadczy o wykonanych tam pracach profilowania koryta. Wyróżniono fragmenty brzegu, na których funkcjonują ubezpieczenia brzegowe różnego typu (kamienny mur oporowy,

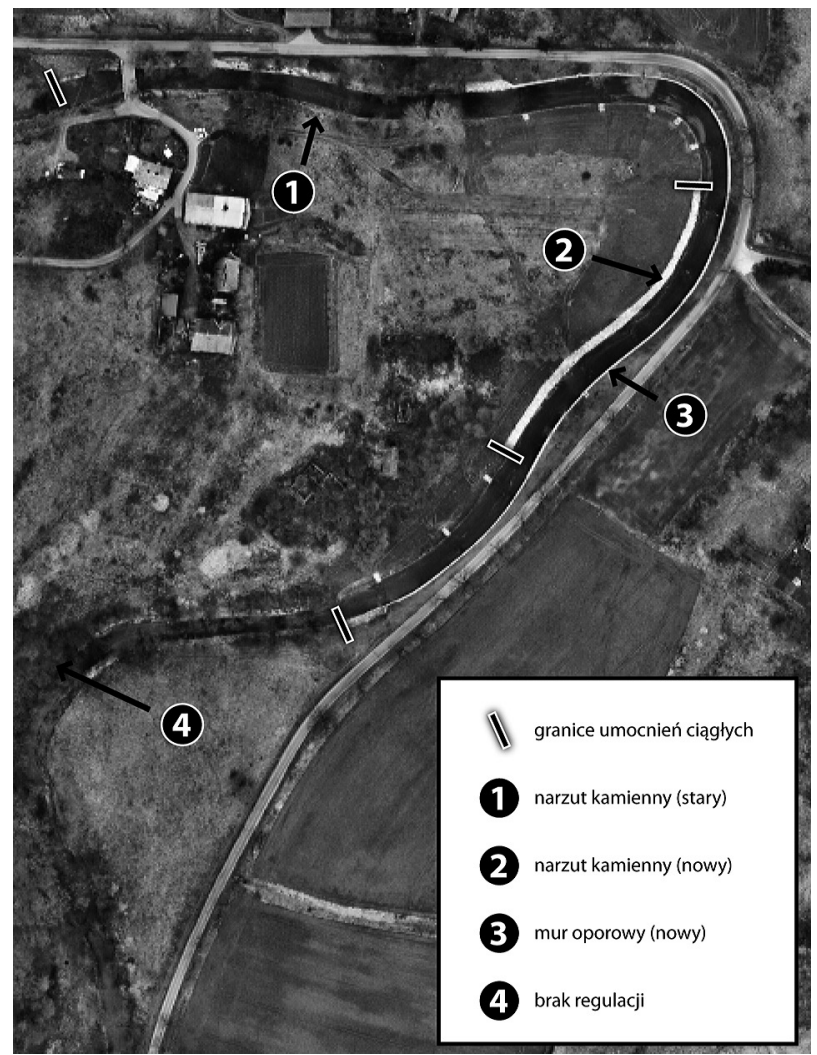

Ryc. 4. Lokalizacja konstrukcji oporowych różnego typu w korycie Bystrzycy Dusznickiej w Szalejowie Dolnym (zdjęcia wykonane 27.11.2012), kierunek biegu rzeki NW-S

Fig. 4. Localization of retaining elements in Bystrzyca Dusznicka channel in Szalejów Dolny (picture taken on 27/11/2012), flow direction NW-S 
okładzina oraz różne rodzaje narzutu kamiennego), pochodzące z kilku okresów regulacji tego fragmentu cieku. Najlepiej widoczne są elementy nowych umocnień, powstałych w latach 2011-2012. Wyrazistość tych form wynika przede wszystkim z braku porośnięcia elementów konstrukcyjnych roślinnością. Materiał skalny i sztuczne elementy betonowe ze względu na krótki czas funkcjonowania w korycie nie uległy jeszcze wyraźnym procesom wietrzenia, z czego wynika ich zdecydowanie jaśniejsza barwa niż konstrukcji wzniesionych w korycie wcześniej.

Rycina 5 pokazuje zróżnicowanie barwne, z jakim mamy do czynienia, wykonując naloty w różnych porach roku. Materiał uzyskany jesienią (ryc. 5a) pozwala na analizę niektórych form korytowych oraz elementów antropogenicznych znajdujących się zarówno nad powierzchnią wody, jak i (miejscami) pod wodą. Ze wzglę- du na wysoki współczynnik albedo zalegającej pokrywy śnieżnej, taki zakres analizy nie jest możliwy na materiale uzyskanym w okresie zimowym (ryc. 5b). Należy jednak zaznaczyć, że powyższe spostrzeżenia dotyczą wyłącznie ortofotomapy lub pojedynczych zdjęć lotniczych nie poddanych dalszym przekształceniom czy filtracji.

Prace regulacyjne w korytach rzecznych przebiegają zazwyczaj etapowo. W przypadku rzek ziemi kłodzkiej ciągłe regulacje długich odcinków przeprowadzane były stosunkowo rzadko. W ostatnich latach wykonano takie prace na kilku odcinkach, w tym na dyskutowanym wyżej zakolu Bystrzycy Dusznickiej w Szalejowie Dolnym. Znacznie częściej przeprowadzane są prace mające na celu modyfikację lub uzupełnienie istniejących już systemów regulacji. Na rycinie 6 przedstawiono odcinek Nysy Kłodzkiej w Krosnowicach, na którym przeprowadzono
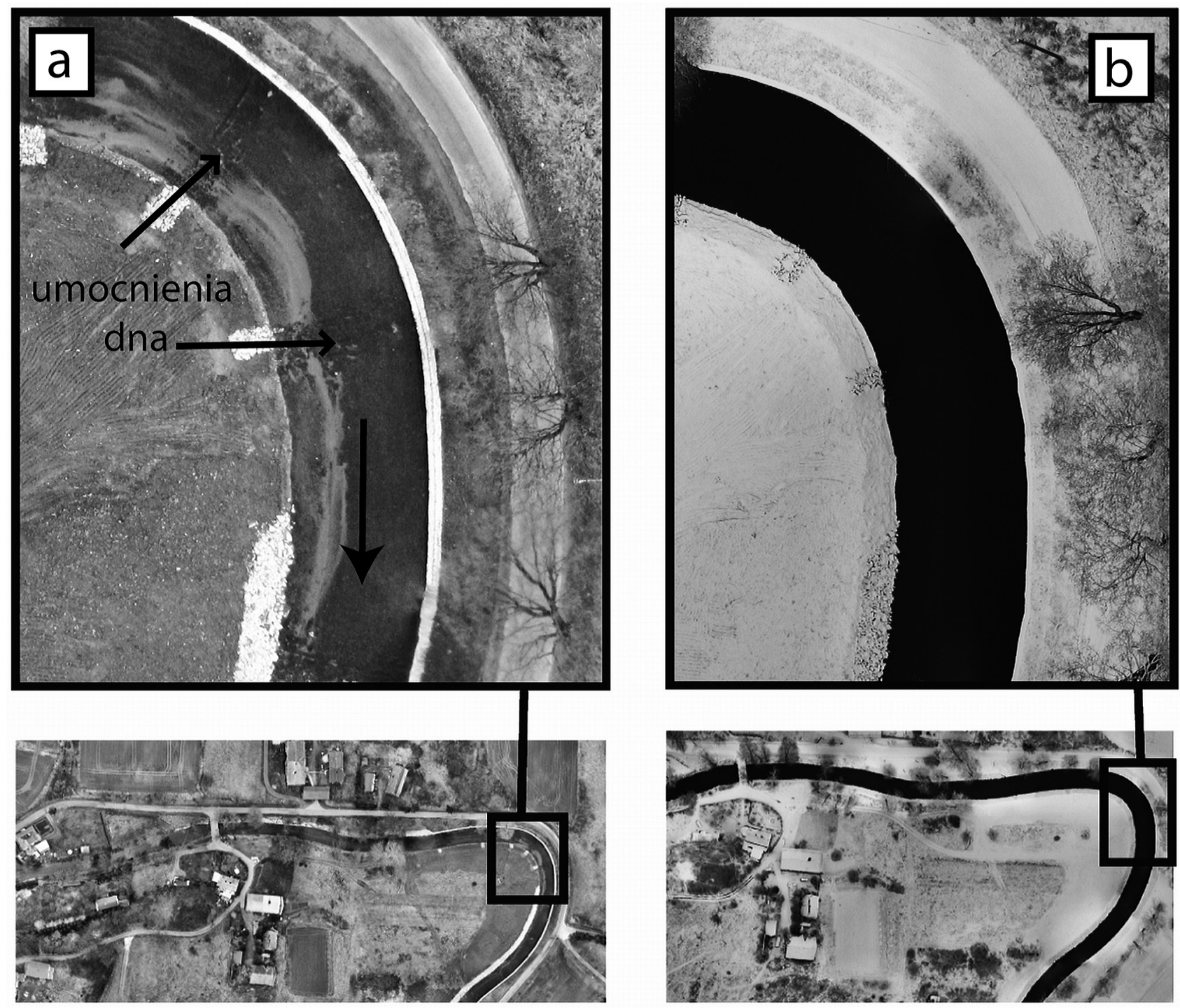

Ryc. 5. Ortofotomapa dla fragmentu koryta Bystrzycy Dusznickiej w Szalejowie Dolnym, zdjęcia wykonane: a - 27.11.2012, b - 8.01.2013; na zdjęciu a widoczne formy akumulacyjne znajdujące się pod wodą, powstałe na wewnętrznym brzegu zakola (prawy brzeg), elementy umocnienia dna, elementy regulacyjne w postaci narzutu kamiennego (prawy brzeg) oraz muru oporowego (lewy brzeg)

Fig. 5. Orthophotomap for Bystrzyca Duszncka (channel section in Szalejów Dolny). Pictures acquired on: a - 27/11/2012, b - 8/01/2013; on the picture a the following elements are visible: accumulation forms under the water surface, established at the inside edge of the meander (right shore), bottom strengthening elements, regulation elements - riprap (right shore) and retaining walls (left shore) 


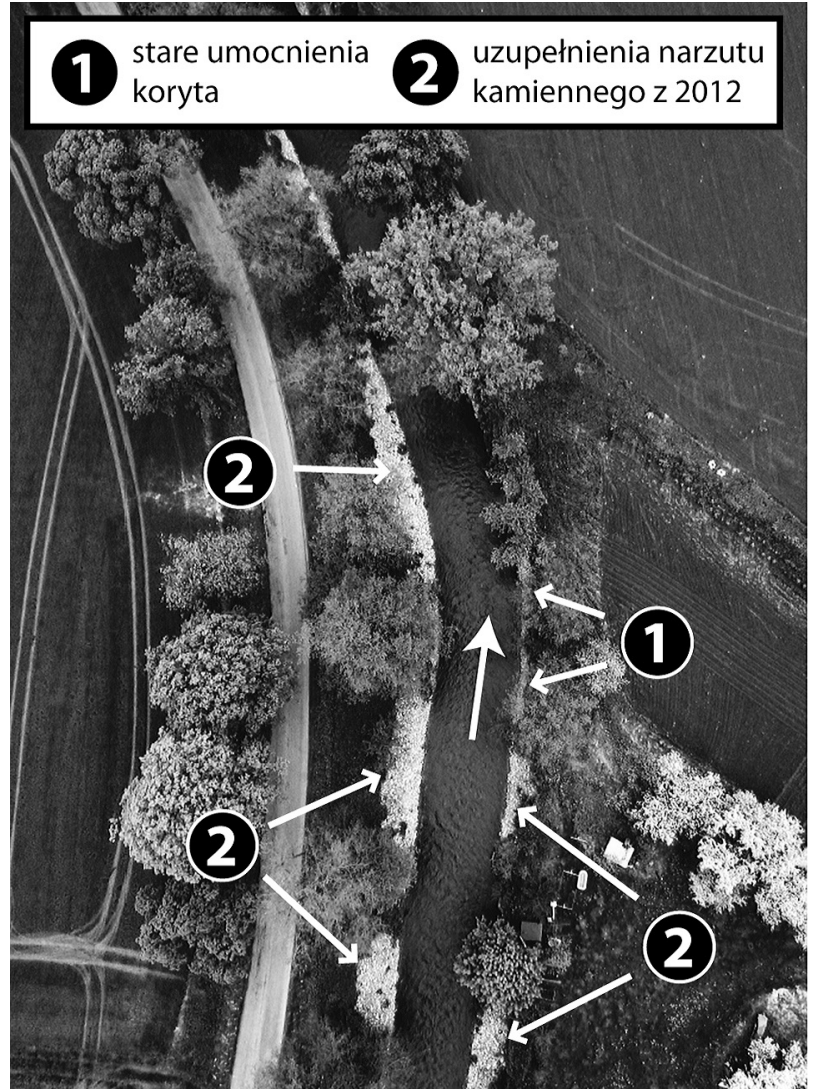

Ryc. 6. Koryto Nysy Kłodzkiej w Krosnowicach, zdjęcie wykonane 13.05.2013; widoczne fragmenty starych umocnień narzutem kamiennym zmodernizowane w 2013 r.

Fig. 6. Channel of Nysa Kłodzka in Krosnowice, picture taken on 13/05/2013, visible parts of old riprap, modernized in 2013

uzupełnienia narzutem kamiennym istniejących w tym miejscu, zniszczonych elementów ubezpieczeń brzegowych. Jaśniejszy foton umożliwia wyróżnienie fragmentów brzegów, na których wykonano takie uzupełnienia. Rycina jest jeszcze nieprzetworzonym zdjęciem lotniczym, które pozwala na dokonanie identyfikacji i inwentaryzacji modernizacji zabezpieczeń brzegów. Po dalszym przetworzeniu na powstałej ortofotomapie będzie możliwy dokładny pomiar długości odcinków, na których przeprowadzono prace, a także pomiar powierzchni nowych elementów zabudowy przeciwerozyjnej.

\section{Wpływ obiektów antropogenicznych na morfologię koryta}

Zabudowa hydrotechniczna w korytach rzecznych jest najczęściej analizowana w kontekście jej wpływu na współczesne funkcjonowanie koryta oraz tworzenie się erozyjnych i akumulacyjnych form rzeźby fluwialnej. Materiał fotogrametryczny uzyskany podczas lotów bezzałogowym statkiem powietrznym pozwolił na identyfikację form rzeźby fluwialnej rozwijających się w strefie oddziaływania obiektów hydrotechnicznych i komunikacyjnych. Na rycinie 7 pokazano proces formowania się zatorów organicznych na filarze mostu drogowego w Gorzuchowie na rzece Ścinawce. Przy tym obiekcie widocz-
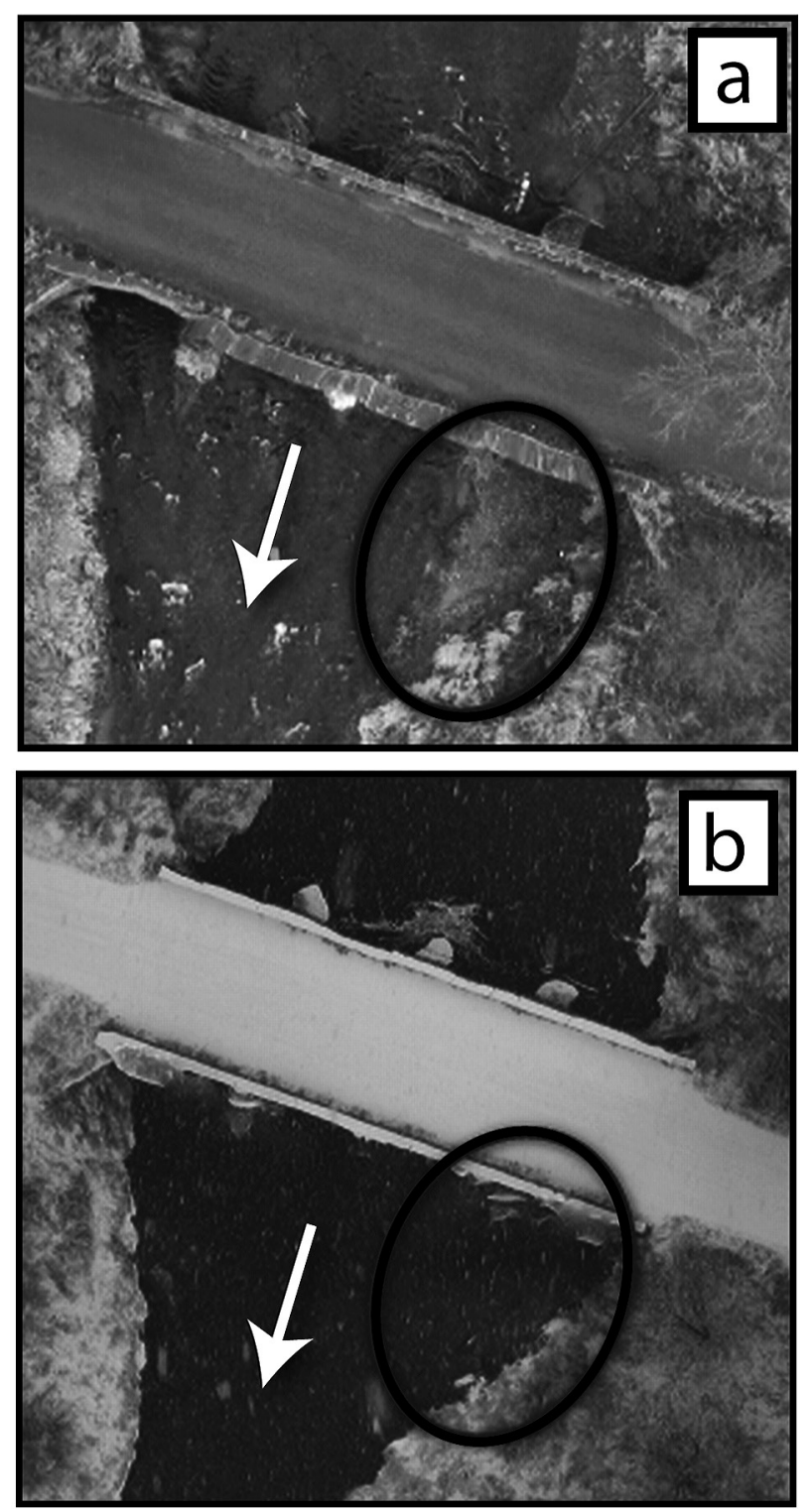

Ryc. 7. Porównanie widoczności form korytowych znajdujących się pod powierzchnią wody w okresie (a) jesiennym i (b) zimowym; koryto Ścinawki w Gorzuchowie; łacha przybrzeżna za przeszkodą

Fig. 7. Comparision of channel forms under the water surface in (a) autumn and (b) winter; channel of Ścinawka in Gorzuchów, downstream of obstruction bar

na jest także łacha przybrzeżna za przeszkodą (ryc. 7a). Forma ta znajduje się pod powierzchnią wody i jest widoczna jedynie na zdjęciach z obserwacji wykonanych w listopadzie 2012 r., a nie jest możliwa do zidentyfikowania na zdjęciach ze stycznia 2013 r. (ryc. 7b).

\section{Formy korytowe na zdjęciach niskiego pułapu}

Zdjęcia lotnicze niskiego pułapu są doskonałym materiałem do analizy rozmieszczenia i morfometrii form korytowych. Wysoka rozdzielczość materiału umożliwia rozpoznanie i charakterystykę niewielkich form rzeźby. Dzięki analizie zdjęć lotniczych lub powstałej na ich podstawie ortofotomapy możliwa jest analiza kształtu 


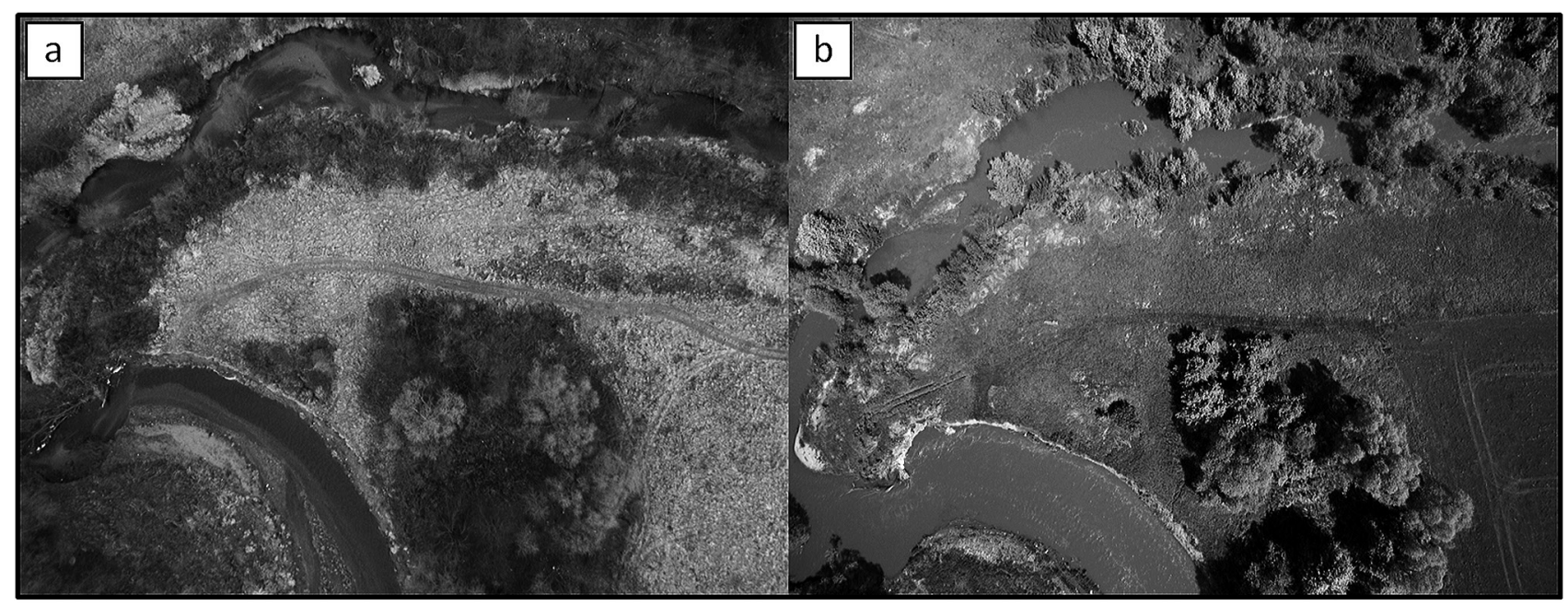

Ryc. 8. Koryto Ścinawki

a - podczas niskiego stanu wody (27.11.2012), b - podczas wezbrania (13.05.2013)

Fig. 8. The channel of Ścinawka

a - during low water level (27/11/2012), b - during flooding (13/05/2013)

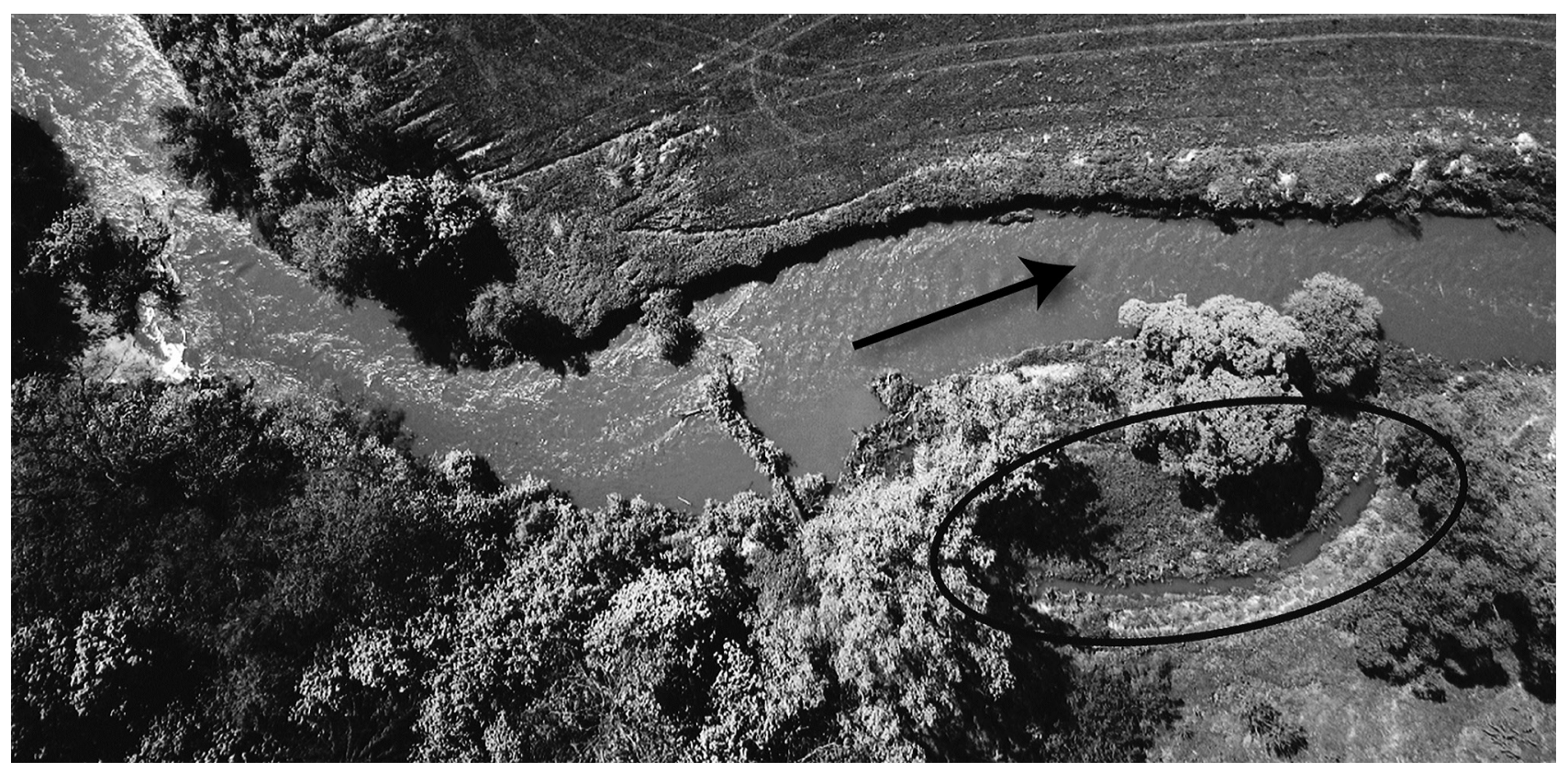

Ryc. 9. Koryto Ścinawki podczas wezbrania w maju 2013 r., zaznaczono wypełnione starorzecze

Fig. 9. Channel of Ścinawka during flooding in May 2013, circled filled oxbow

form akumulacyjnych (ryc. 5a, 7a, 8a). Materiał lotniczy pozwala także na identyfikację form erozji bocznej (ryc. 8a, 9), a na podstawie zróżnicowanych odcieni szarości w obrębie koryta można podjąć próbę identyfikacji form korytowych znajdujących się pod wodą (ryc. 5a, 7a, 8a). Fotony jaśniejsze sugerują miejsca wypłyceń koryta, gdzie w dnie występują i rozwijają się formy akumulacyjne (ryc. 5a, 7a, 8a). Ciemniejsze kolory na zdjęciach oznaczają miejsca przegłębień w korycie. Takie miejsca mogą tworzyć się naturalnie lub ściśle wiązać się z obiektami antropogenicznymi, np. przegłębienia dna poniżej obiektów piętrzących, takich jak jazy, progi czy stopnie. Materiał uzyskany za pomocą bezzałogowego statku powietrznego nadaje się do inwentaryzacji form rzeźby, których dokładne rozpoznanie na drodze tradycyjnych badań terenowych jest w pewnym stopniu utrudnione. Niedogodności takie mogą wynikać z niedostępności lub trudności w eksploracji danego obszaru (np. obszary zabagnione, strome ściany skalne, szerokie rzeki, zbiorniki wodne) lub z własności samych form rzeźby (np. formy wielkoobszarowe, formy niewidoczne $\mathrm{w}$ całości z powierzchni ziemi, np. paleokoryta, starorzecza). W takich przypadkach wysokorozdzielcze zobrazowania z powietrza są najlepszym materiałem do analizy. Na rycinie 9 widoczne jest dodatkowe koryto Ścinawki w okolicach Gorzuchowa wypełniające się wodą jedynie w przypadkach wysokich stanów wody (zobrazowanie z 13 maja 2013 r.). 


\section{Epizody wezbraniowe}

Zdjęcia lotnicze oraz wysokorozdzielcza ortofotomapa mogą być wykorzystane do analizy wypełnienia koryta podczas zdarzeń wezbraniowych, a także do określenia obszaru zalania w trakcie powodzi. Loty wykonane na początku maja 2013 r. na ziemi kłodzkiej odbyły się w okresie niewielkiego wezbrania na rzekach ziemi kłodzkiej po kilkudniowych intensywnych opadach. Zestawienie zdjęć wykonanych nad korytem Ścinawki w listopadzie 2012 r. i w maju 2013 r. pokazuje, jak zmieniło się wypełnienie koryta rzeki (ryc. 8). Podczas tego niewielkiego wezbrania nie nastąpiło wylanie się wody z koryta, jednak wypełniły się wodą np. niektóre skróty powodziowe utworzone w przeszłości przez Ścinawkę, a także niektóre starorzecza znajdujące się w bezpośrednim sąsiedztwie obecnego koryta rzeki (ryc. 9). Na rycinie 8a podczas niskiego stanu wody widoczne są niektóre formy akumulacyjne pod powierzchnią wody. Oprócz wspomnianej wcześniej możliwości rozpoznania miejsc przegłębień i wypłyceń w korycie, możliwe jest też określenie charakterystyk nurtu. W przypadku zdjęć wykonanych w okresie wezbrania (ryc. 8b) można zidentyfikować jedynie duże formy akumulacyjne, których przynajmniej fragmenty znajdują się ponad lustrem wody. Utrudnione jest również zidentyfikowanie wszystkich nisz i podcięć erozyjnych (część form znajduje się pod wodą).

\section{Nowe ortofotomapy o wysokiej rozdzielczości}

Postępując zgodnie z procedurą opisaną powyżej, przygotowano osiem ortofotomap i osiem numerycznych modeli terenu. Przetworzono materiał obserwacyjny pozyskany podczas lotów bezzałogowego statku powietrznego zrealizowanych w okolicach posterunków wodowskazowych w Gorzuchowie na Ścinawce, Szalejowie Dolnym na Bystrzycy Dusznickiej oraz Żelaźnie na Białej Lądeckiej, należących do Lokalnego Systemu Osłony Przeciwpowodziowej Powiatu Kłodzkiego (loty wykonane 27.11.2012 oraz 8.01.2013).

Dla każdej kampanii obserwacyjnej wygenerowana została odrębna ortofotomapa. Przygotowując materiał do ortorektyfikacji, uwzględniono podobszar, w którym pokrycie poprzeczne i podłużne było pełne. Rozdzielczość została ustawiona na najwyższą możliwą przy wykorzystaniu dostępnego materiału. Terenowa wielkość piksela na tych ortofotomapach wynosiła około $3 \mathrm{~cm}$. W przygotowaniu ortofotomapy nie uwzględniono fotopunktów. Na rycinie 5 powiększone fragmenty pokazują, że przy uzyskanej rozdzielczości możliwe jest wykrycie nawet małych zmian w obrębie koryta rzeki oraz jego sąsiedztwa. Ten sam obszar obserwacji oraz podobna rozdzielczość sprawiają, że obie ortofotomapy są porównywalne.
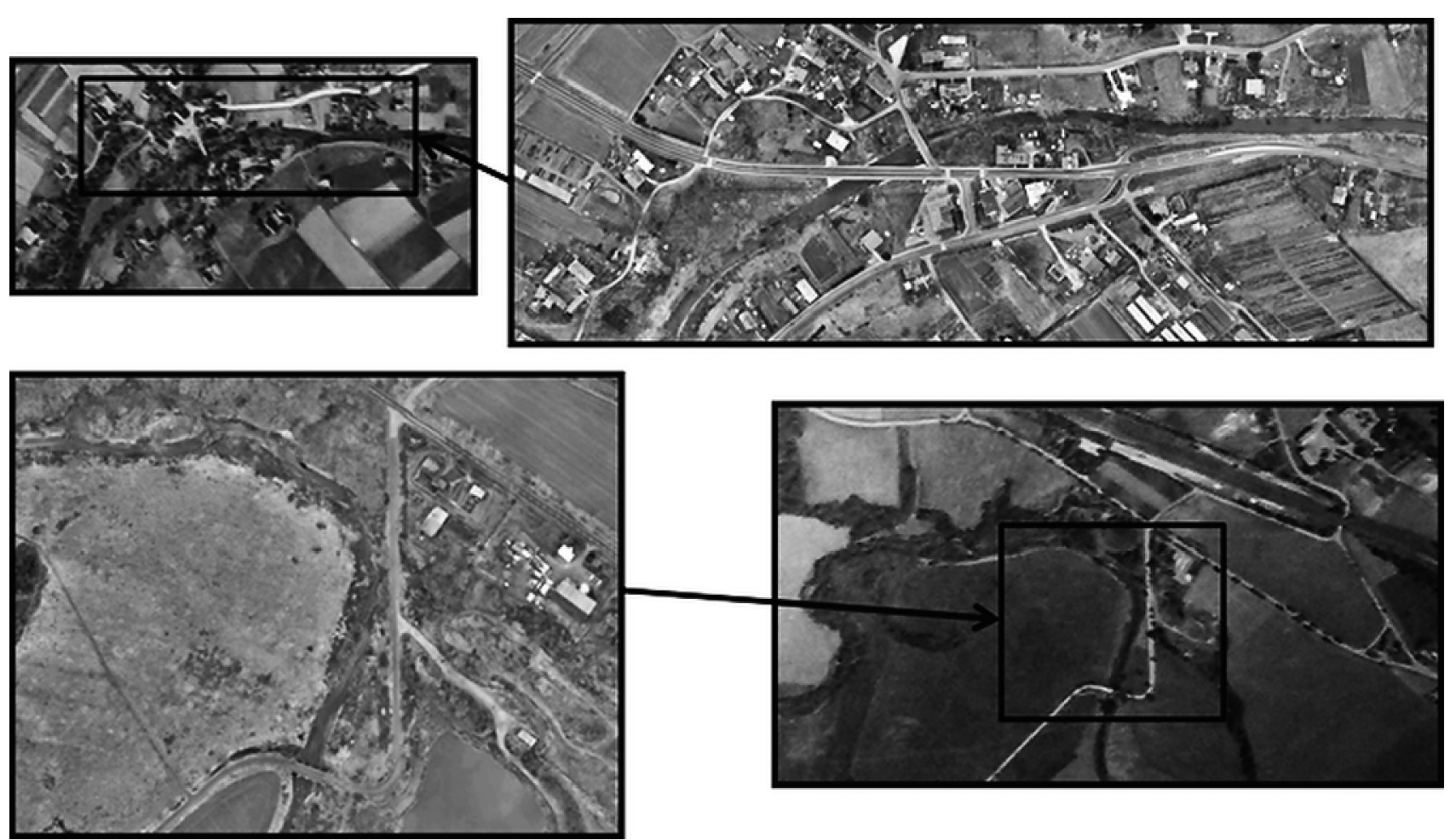

Ryc. 10. Porównanie szczegółowości ortofotomapy powstałej za pomocą tradycyjnych metod fotogrametrycznych z ortofotomapą tego samego obszaru wygenerowaną ze zdjęć lotniczych wykonanych bezzałogowym statkiem powietrznym

Fig. 10. Comparision of level of detail of orthophotomap created using traditional photogrammetric methods and orthophotomap of the same area generated from photos acquired with UAV 


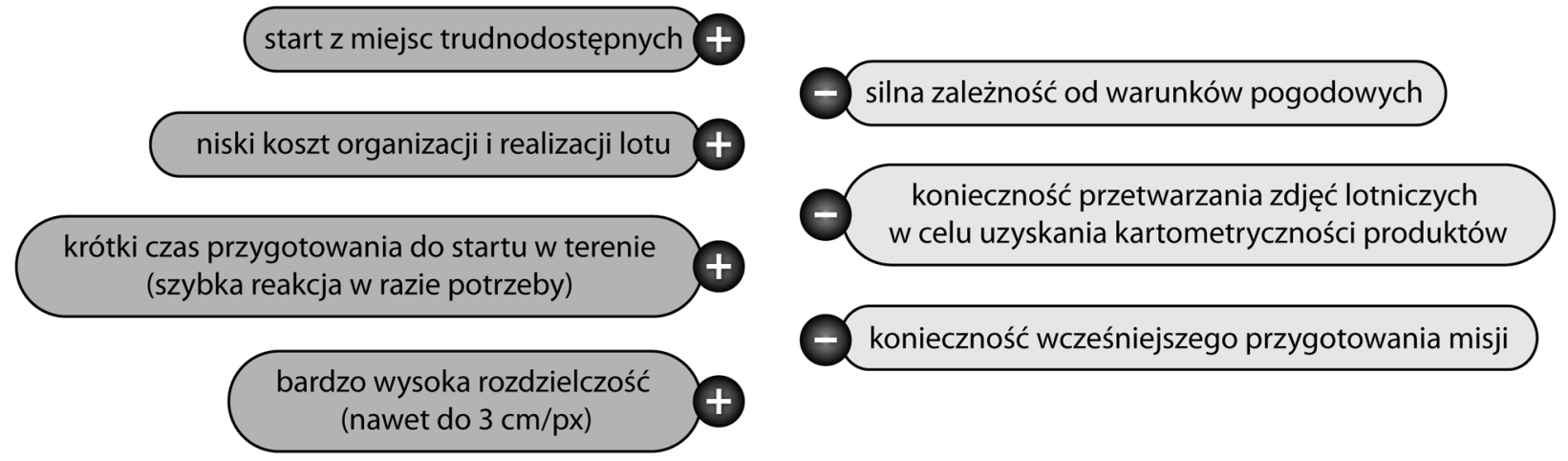

Ryc. 11. Zalety i wady pozyskiwania danych przestrzennych z zastosowaniem bezzałogowego statku powietrznego

Fig. 11. Advantages and disadvantages of spatial data acquisition using Unmanned Aerial Vehicle

\section{Wnioski}

Bezzałogowy statek powietrzny do zastosowań fotogrametrycznych i teledetekcyjnych swinglet CAM pozwala na pozyskanie materiału o wysokiej rozdzielczości przestrzennej i czasowej, przydatnego do analiz hydrologicznych i geomorfologicznych, w tym do identyfikacji przekształceń antropogenicznych w korytach rzecznych. Fotogrametria z zastosowaniem zdjęć lotniczych niskiego pułapu stanowi nowe podejście do pozyskiwania danych przestrzennych. Przetwarzanie takiego materiału obserwacyjnego jest jednak niejednokrotnie utrudnione. Ilościowa analiza zmian fluwialnych jest możliwa na podstawie ortofotomapy, która jest budowana w procesie przetwarzania zbioru zdjęć lotniczych. W odpowiednich warunkach meteorologicznych i hydrologicznych możliwa jest również charakterystyka form znajdujących się pod powierzchnią wody. Opisane w publikacji podejście do pozyskiwania danych przestrzennych nie jest jednak pozbawione niedoskonałości, wśród których największą niedogodnością jest silna zależność od warunków pogodowych. Zestawienie zalet $\mathrm{i}$ wad omawianego sprzętu przedstawiono na rycinie 11 . Nie bez znaczenia dla przydatności opisywanego sprzętu jest ekonomiczny aspekt jego użytkowania. Bezzałogowe obserwacje lotnicze - w porównaniu do pomiarów terenowych czy tradycyjnego nalotu fotogrametrycznego - charakteryzują się niskimi kosztami realizacji oraz pewnym stopniem elastyczności w zakresie dostosowania czasu i miejsca oraz parametrów lotu. Łącząc wysoką rozdzielczość z niską czasochłonnością i niskimi kosztami, bezzałogowa fotogrametria lotnicza wypełnia lukę między pomiarami terenowymi a wielkoobszarowymi zobrazowaniami lotniczymi, które charakteryzują się mniejszą rozdzielczością. Podczas planowania i realizacji lotu bezzałogowym statkiem powietrznym należy zawsze uwzględniać formalnoprawne uwarunkowania korzystania z przestrzeni powietrznej.

\section{Podziękowania}

Badania zostały sfinansowane ze środków na badania statutowe Instytutu Geografii i Rozwoju Regionalnego Uniwersytetu Wrocławskiego oraz w ramach projektu pt. ,System wspierający porównywanie prognoz hydrologicznych” nr 2011/01/D/ST10/04171 (HydroProg), wspieranego przez Narodowe Centrum Nauki i realizowanego pod kierunkiem dr. hab. prof. UWr Tomasza Niedzielskiego. Autorzy dziękują również władzom i pracownikom Starostwa Powiatowego w Kłodzku, będącego oficjalnym partnerem projektu HydroProg. Wszystkie loty bezzałogowego statku powietrznego realizowano zgodnie z wymogami Polskiej Agencji Żeglugi Powietrznej i w porozumieniu $\mathrm{z}$ tą instytucją.

\section{Literatura}

Bates P.D., De Roo A.P.J., 2000. A simple raster-based model for flood inundation simulation. Journal of Hydrology 236(1-2): 54-77.

Brasington J., Rumsby B.T., McVey R.A., 2000. Monitoring and modelling morphological change in a braided gravel-bed river using high resolution GPS-based survey. Earth Surface Processes and Landforms 25: 973-990.

Chiabrando F., Nex F., Piatti D., Rinaudo F., 2011. UAV and RPV systems for photogrammetric surveys in archaelogical areas: two tests in the Piedmont region (Italy). Journal of Archaeological Science 38: $697-710$.

Dobrowolski A., Głowacka B., Krupa-Marchlewska J., 2004. Określenie zmian morfologicznych koryta Wisły powyżej Warszawy w oparciu o lotnicze zobrazowania terenu metodą wideo-komputerową. Teledetekcja Środowiska 33: 52-57.

Grenzdörfer G.J., Guretzki M., Friedlander I., 2008. Photogrammetric image acquisition and image analysis of oblique imagery - a new challenge for the digital airborne system PFIFF. Photogrammetric Record 12/2008: 372-386.

Herget J., 2000. Holocene development of the River Lippe Valley, Germany: A case study of anthropogenic influence. Earth Surface Processes and Landforms 25: 295-305.

Kasprzak M., Migoń P., 2010. Prognozowanie geomorfologicznych skutków wezbrań i powodzi. W: P. Migoń (red.), Wyjątkowe zdarzenia przyrodnicze na Dolnym Śląsku i ich skutki. Rozprawy Naukowe Instytutu Geografii i Rozwoju Regionalnego Uniwersytetu Wrocławskiego 14: 269-290. 
Knight D.W., Brown F.A., 2001. Resistance studies of overbank flow in rivers with sediment using the flood channel. Journal of Hydraulic Research 39: 283-301.

Kondolf G.M., 1997. Hungry water: effects of dam and gravel mining on river channels. Environmental Management 21(4): 533-551.

Korpak J., 2007a. Morfologiczna rola budowli regulacyjnych w górskich systemach fluwialnych. Praca doktorska. Uniwersytet Jagielloński, Kraków: 277.

Korpak J., 2007b. The influence of mountain river training on Chanel changes (Polish Carpathian Mountains). Geomorphology 92: 166181.

Korpak J., Krzemień K., Radecki-Pawlik A., 2009a. Wpływ budowli regulacyjnych i poboru rumowiska na koryta rzek i potoków górskich - wybrane przykłady z rzek karpackich. Gospodarka Wodna 7: 274-281.

Korpak J., Krzemień K., Radecki-Pawlik A., 2009b. Wpływ działalności człowieka na funkcjonowanie górskich systemów fluwialnych. Czasopismo Techniczne 2-A, 10. Wydawnictwo Politechniki Krakowskiej.

Kościelniak J., 2005. Skuteczność hydrotechnicznych regulacji koryta górskiej rzeki na przykładzie Białego Dunajca. W: A. Kotarba, K. Krzemień, J. Święchowicz (red.), Współczesna ewolucja rzeźby Polski. IGiGP UJ, Kraków: 221-226.

Küng O., Strecha C., Beyeler A., Zufferey J.-C., Floreano D., Fua P., Gervaix F., 2011. The accuracy of automatic photogrammetric techniques on ultra-light UAV imagery. International Archives of the Photogrammetry. Remote Sensing and Spatial Information Sciences XXXVIII-1/C2: 125-130.

Lane S.N., 2000. The measurement of river channel morphology using digital photogrammetry. The Photogrammetric Record 16: 937-961.

Latocha A., 2009. Wpływ działalności człowieka na procesy korytowe na przykładzie Nysy Kłodzkiej między Bystrzycą Kłodzką a Kłodzkiem. Przyroda Sudetów 12: 99-122.

Loveless J.H., Sellin R.H.J., Bryant T.B., Wormleaton P.R., Catmur S., Hey R., 2000. The effect of overbank flow in a meandering river on its conveyance and the transport of graded sediments. Water and Environment Journal 14: 447-455.

Marcus W.A., Fonstad M.A., 2008. Optical remote mapping of rivers at sub-meter resolution and watershed extents. Earth Processes and Landform 33: 4-24.

Mikuni A.M., 1996. Digital Orthophoto Production. W: C. Greve (red.), Digital Photogrammetry - An Addendum to the Manual of Photogrammetry. American Society of Photogrammetry, Bethesda, MD.

Niethammer U., James M.R., Rothmund S., Travelletti J., Joswig M., 2012. UAV-based remote sensing of the Super-Sauze landslide: Evaluation and results. Engineering Geology 128: 2-11.

Paine D., Kiser J., 2003. Aerial Photography and Image Interpretation. 2nd ed. John Wiley \& Sons, Inc., Hoboken, New Jersey.

Radecki-Pawlik A., Bencal J., Kowalski M., Radecki-Pawlik B., 2005. Zróżnicowanie warunków hydrodynamicznych i granulometrycznych podczas tworzenia się łachy środkowo-korytowej w potoku górskim o dnie żwirowym. Infrastruktura i Ekologia Terenów Wiejskich 4: 115-130

Shaw E.M., Beven K.J., Chappell N.A., Lamb R., 2011. Hydrology in Practice. Fourth Ed. Spon Press (Taylor and Francis), London.

Singh M., Singh I.B., Müller G., 2007. Sediment characteristics and transportation dynamics of the Ganga River. Geomorphology 86: $144-175$.

Slama C. (red.), 1980. Manual of Photogrammetry. American Society of Photogrammetry, Falls Church, VA.

Słowik M., 2011. Changes of river bed pattern and traces of anthropogenic intervention: The example of using GPR method (the Obra River, western Poland). Applied Geography 31: 784-799.
Somodi I., Carni A., Ribeiro D., Podobnikar T., 2012. Recognition of the invasive species Robinia pseudacacia from combined remote sensing and GIS sources. Biological Conservation 150: 59-67.

Surian N., 1999. Channel changes due to river regulation: the case of the Piave River, Italy. Earth Surface Processes and Landforms 24: 1135-1151.

Tarboton D.G., Bras R.L., Rodriguez-Iturbe I., 2006. On the extraction of channel networks from digital elevation data. Hydrological Processes, Special Issue: Digital Terrain Modelling in Hydrology 5(1): 81-100.

Turner D., Lucieer A., Watson C., 2012. An Automated Technique for Generating Georectified Mosaics from Ultra-High Resolution Unmanned Aerial Vehicle (UAV) Imagery, Based on Structure from Motion (SfM) Point Clouds. Remote Sensing 4: 1392-1410.

Vallet J., Panissod F., Strecha C., Tracol M., 2011. Photogrammetric Performance of an Ultra Light Weight Swinglet "UAV". W: H. Eisenbeiss, M. Kunz, H. Ingensand (red.), SPRS Archives, Vol. XXXVIII-1/ C22, International Conference on Unmanned Aerial Vehicle in Geomatics (UAV-g), 14-16 September, Zurich, Switzerland: 253-258.

Vandenberghe J., van Overmeeren R.A., 1999. Ground penetrating radar images of selected fluvial deposits in the Netherlands. Sedimentary Geology 128: 245-270.

Vassilopoulou S., Hurni L., Dietrich V., Baltsavias E., Pateraki M., Lagios E., Parcharidis I., 2002. Orthophoto generation using IKONOS imagery and high-resolution DEM: a case study on volcanic hazard monitoring of Nisyros Island (Greece). ISPRS Journal of Photogrammetry and Remote Sensing 57: 24-38.

Verbanck M.A., 2008. How fast can a river flow over alluvium? Journal of Hydraulic Research 46, Supplement 1: 61-71.

Verhoeven G., Doneus M., Briese C., Vermeulen F., 2012. Mapping by matching - A computer vision-based approach to fast and accurate georeferencing of archaeological aerial photographs. Journal of Archaeological Science 39: 2060-2070.

Warmink J.J., Dohmen-Janssen C.M., Schielen R.M.J., 2012. Bed form evolution under varying discharges, flume versus field. W: R.R. Murillo Muñoz, River Flow 2012. Taylor \& Francis Group, London: 183-190.

Wieczorek B., Glińska-Lewczuk K., Sobieraj A., 2012. Geoinformation technologies in the identification of meandering section of the river. W: R. Seppelt, A.A. Voinov, S. Lange, D. Bankamp (red.), Proceedings of 2012 International Congress on Environmental Modelling and Software.

Witek M., 2007. Wpływ zabudowy hydrotechnicznej na procesy w korycie Bystrzycy Dusznickiej. MS, Wrocław: 207.

Witek M., 2010a. Funkcjonowanie górskich systemów fluwialnych w warunkach regulacji na przykładzie koryta Ścinawki pomiędzy Ścinawką Dolną a Kłodzkiem. Przyroda Sudetów 13: 275-292.

Witek M., 2010b. Obiekty hydrotechniczne a rozmieszczenie stref erozji i akumulacji - problematyka koryt uregulowanych na ziemi kłodzkiej. W: Współczesne trendy w naukach o Ziemi. III Geosympozjum Młodych Badaczy Silesia 2010. Bytom-Sucha Góra: 242-255.

Witek M., 2012. Wpływ zabudowy hydrotechnicznej na współczesne kształtowanie rzeźby koryt rzek ziemi kłodzkiej. Landform Analysis 9: 91-102.

Witek M., Latocha A., 2009. Zabudowa hydrotechniczna Bystrzycy Dusznickiej w warunkach zmian społeczno-gospodarczych w ciągu ostatnich 100 lat. W: W. Bochenek, M. Kijowska (red.), Zintegrowany monitoring środowiska przyrodniczego. Funkcjonowanie środowiska przyrodniczego w okresie przemian gospodarczych w Polsce. Biblioteka Monitoringu Środowiska, Szymbark: 154-171.

Wolf P.R., Dewitt B.A., 2000. Elements of Photogrammetry with Applications in GIS. 3rd ed. McGraw-Hill, New York. 